\title{
Media dan Upaya Mempertahankan Tradisi dan Nilai-nilai Adat
}

\author{
Alfin Syah Putra ${ }^{1}$ dan Teguh Ratmanto ${ }^{2 *}$ \\ ${ }_{1,2}^{1,}$ Universitas Islam Bandung \\ E-mail: alfinsyahputraa@gmail.comdan teguh_ratman@yahoo.com² \\ *corresponding author
}

Keywords:

media, communication activities, adat society, traditions

\begin{abstract}
The adat society of Cireundeu is the society who lives in the village of Cireundeu, Leuwigajah, South Cimahi subdistrict, Cimahi City. The adat society of Cireundeu are the people who uphold the customs of Sundanese culture, especially the culture, traditions and customary values passed down by their ancestors or can be called as Sesepuh. The society of Cireundeu, though close to the city and open to technology, can retain their traditions and customary values. Some of the Traditions in Cireundeu that still survive until now are Sura'an tradition, the tradition of eating cassava and Pikukuh Tilu. The existence of this tradition because of the role of communication made by Cireundeu adat society in maintaining the traditions and custom values. This research to study the media role in communication activities of adat society of Cireundeu village in maintaining the tradition and custom values.

The Research used qualitative method and study case approach to present a comprehensive presentation about the group communication activities of adat society of Cireundeu village from the subject point of view.

The results of research showed that the role of the media on group communication activities of adat society of Cireundeu in maintaining the traditions and customs was through conventional mass media for outsiders community coming to Cireundeu, and social media insider community especially tennagers.
\end{abstract}

\begin{abstract}
ABSTRAK
Masyarakat adat kampung Cireundeu adalah masyarakat yang tinggal di kampung Cireundeu Kelurahan Leuwigajah, Kecamatan Cimahi Selatan, Kota Cimahi. Masyarakat adat kampung Cireundeu adalah masyarakat yang menjunjung tinggi adat budaya Sunda, terutama budaya, tradisi dan nilai-nilai adat yang diturun-temurunkan oleh nenek moyang mereka atau biasa disebut Sesepuh. Masyarakat kampung Cireundeu meski berdekatan dengan daerah kota dan terbuka terhadap teknologi mereka tetap dapat mempertahankan tradisi dan nilai-nilai adat yang mereka miliki. Tradisi di Cireundeu yang masih bertahan hingga kini beberapa diantaranya Tradisi Sura'an, tradisi mengonsumsi Singkong dan Pikukuh Tilu. Bertahannya tradisi ini tidak luput dari peran komunikasi yang dilakukan masyarakat adat Cireundeu dalam mempertahankan tradisi dan nilai adat. Penelitian ini mengkaji peran media pada aktivitas komunikasi masyarakat adat kampung Cireundeu dalam mempertahankan tradisi dan nilai-nilai adat.

Pendekatan dalam penelitian ini menggunakan Metode kualitatif dengan pendekatan Studi Kasus agar dapat menyajikan paparan yang komprehensif tentang aktivitas komunikasi kelompok masyarakat adat kampung Cireundeu dari sudut pandang subjek.

Hasil penelitian menunjukkan bahwa peran media pada aktivitas komunikasi kelompok masyarakat adat kampung Cireundeu dalam mempertahankan tradisi dan nilai adat yaitu melalui media massa konvensional untuk masyarakat eksternal dan media sosial untuk masyarakat internal, khususnya remaja.
\end{abstract}

Copyright (C) 2019 Channel Jurnal Komunikasi. All right reserved. 


\section{PENDAHULUAN}

Kondisi masyarakat selalu berubah sesuai dengan perkembangan zaman dimana perubahan itu mempengaruhi seluruh aspek hidup mereka. Perubahan ini terjadi karena pada dasarnya manusia adalah makhluk yang dinamis. Manusia hidup dan tinggal di dalam suatu lingkungan yang serba melembaga. Hal ini berarti bahwa segala tindak tanduk atau perilaku manusia senantiasa diatur menurut cara-cara tertentu yang telah disepakati bersama. Koentjaraningrat (1990:164) menyebutkan bahwa pranata adalah: "Suatu sistem norma khusus yang menata suatu rangkaian tindakan guna memenuhi suatu keperluan khusus dari manusia dalam kehidupan bermasyarakat." Salah satu bentuk lingkungan sosial yang melembaga adalah desa atau kampung.

Cireundeu adalah kampung yang terletak di daerah Kelurahan Leuwi Gajah, Kecamatan Cimahi Tengah. kampung adat Cireundeu sendiri memiliki karakteristik masyarakat yang unik dan dapat dikatakan membanggakan. Keunikannya adalah mereka merupakan masyarakat pengonsumsi singkong dan mereka adalah masyarakat yang menjunjung tinggi nilai-nilai dan tradisi adat Sunda. Tradisi makan singkong yang sudah lama bertahan di kampung adat Cireundeu ini juga menjadi perhatian secara nasional, pada tahun 2008 Menteri Pertanian memberikan piagam penghargaan kepada kampung adat Cireundeu. Selain tradisi mengonsumsi Singkong, beberapa tradisi dan nilai adat yang ada di Cireundeu yaitu tradisi Pikukuh Tilu, olah rasa, olah tubuh, dan kepercayaan Sunda Wiwitan.

Masyarakat adat Cireundeu tidak terpisah dengan masyarakat lain karena mereka adalah masyarakat yang terbuka terhadap perkembangan zaman dan teknologi, mereka tidak pernah menolak perkembangan teknologi yang masuk ke kampung mereka. Meski masyarakat adat kampung Cireundeu menggunakan teknologi komunikasi dan sudah terbiasa dengan modernisasi, mereka tetap teguh dalam memegang tradisi mereka. Setelah puluhan tahun hingga ratusan tahun berlalu, masyarakat adat kampung Cireundeu hingga kini masih bertahan dalam melakukan tradisi dan nilai-nilai lokal yang ada di lingkungan mereka. Penelitian ini akan mengkaji peranan media dalam melesarikan nilai-nilai adat dan tradisi masyarakat kampung adat Cireundeu dengan menggunakan metode penelitian kualitatif dengan pendekatan studi kasus.

Fauzan dan Nashar (2017:8) menyebutkan bahwa Pemerintah, khususnya pemerintah daerah berperan dalam melestarikan nilai-nilai adat dan tradisi. Sementara itu Sularso dan Maria (2017) menyebutkan bahwa upaya pelestarian nilai adat dan tradisi dapat dilakukan melalui kegiatan ekstra kurikuler bagi siswa SMP. Upaya pelestarian nilai dan tradisi ini, tentu tidak terlepas dari peran komunikasi yang dilakukan oleh seluruh kalangan masyarakat yang ada di kampung Cireundeu dalam rangka mempertahankan tradisi dan nilai-nilai ini. Seiring dengan perkembangan zaman maka teknologi komunikasipun masuk ke masyarakat Cirendeu. Oleh karena itu, makalah ini akan mengkaji peran teknologi komunikasi dalam mempertahankan nilai-nilai dan tradisi di kampung adat Cireundeu. Maka berdasarkan uraian singkat yang telah dipaparkan di atas artikel ini akan membahas "Bagaimana cara masyarakat adat kampung Cireundeu memanfaatkan teknologi komunikasi dalam mempertahankan tradisi dan nilai-nilai adat?”.

\section{METODE PENELITIAN}

Penelitian ini, berusaha mengkaji peranan media dalam melestarikan nilai-nilai adat dan tradisi pada masyarakat adat Cireundeu. Robert K Yin, menyebutkan bahwa "Studi kasus adalah suatu inkuiri empiris yang menyelidiki fenomena di dalam konteks kehidupan nyata, bilamana batas-batas antara fenomena dan konteks tak tampak dengan tegas, dan dimana; multisumber dimanfaatkan“ (Yin, 2009:18), Tokoh adat dan dan beberapa narasumber diwawancarai untuk memperoleh data yang kemudian dianalisis

\section{LANDASAN TEORI}

\section{A. Internet dan Media Sosial}

Data terbaru dari We Are Social, pengguna internet aktif di seluruh dunia kini mencapai angka 3,17 miliar dengan angka rata-rata pertumbuhannya dari tahun ke tahun,mencapai 7,6\%. Pertumbuhan penggunaan internet ini juga berpengaruh terhadap pertumbuhan pengguna media sosial dan mobile. Lebih lanjut, dilaporkan bahwa pengguna media sosial aktif kini mencapai 2,2 miliar, sedangkan pengguna mobile mencapai 3,7 miliar. Satu hal yang menarik adalah bahwa pertumbuhan yang paling signifikan ditunjukkan oleh pengguna yang mengakses media sosial melalui platform mobile. Pengguna jenis ini bertumbuh hingga 23,3\%. Sementara itu, facebook masih menjadi media sosial yang paling banyak digunakan dengan angka mencapai hampir 1,5 miliar. (https://id.techinasia.com/talk/statistikpengguna-internetdan-media-sosial-terbaru/, diaksestanggal 16 Maret 2017 pukul 23.05 WIB. )

Media Sosial WhatsApp yang sering disingkat WA adalah salah satu media komunikasi yang dapat di install dalam Smartphone. Media sosial ini digunakan sebagai sarana komunikasi chat dengan saling mengirim pesan teks, gambar, video bahkan telpon. Media ini dapat aktif jika kartu telpon pengguna memiliki paket data internet. Penjelasan lebih ditail mengenai WatsApp sebagaimana dikatakan oleh Hartanto, bahwa

WhatsApp adalah aplikasi pesan untuk smartphone dengan basik mirip Black Berry Messenger. WhatsApp Messenger merupakan aplikasi pesan lintas platform yang memungkinkan orang dapat bertukar pesan tanpa biaya SMS, karena WhatsApp Messenger menggunakan paket data internet yang sama untuk email, browsing web, dan lain-lain. Aplikasi WhatsApp Messenger menggunakan koneksi 3G/4G atau WiFi untuk komunikasi 
data. Dengan menggunakan WhatsApp, kita dapat melakukan obrolan online, berbagi file, bertukar foto, dan lain-lain. (Hartanto, 2010:100)

Teknologi komunikasi kini telah membawa dampak yang begitu besar dalam kehidupan manusia dan masyarakat. Setiawan (2018) menyebutkan bahwa begitu cepatnya perkembangan Teknologi Informasi dan Komunikasi mengakibatkan dampak dan pengaruh terhadap budaya pada masyarakat, baik berupa dampak positif maupun dampak negatif.

\section{B. Komunikasi dan Penjagaan dan Pewarisan Tradisi}

Menurut Berelson dan Steiner (dalam Mulyana 2012: 68) "Komunikasi juga dapat diartikan sebagai proses transmisi informasi, gagasan, emosi yang disampaikan melalui simbol-simbol berupa kata-kata, gambar, figur, grafik dan sebagainya. Tindakan atau proses transmisi itulah yang biasanya disebut komunikasi." Dari definisi ini komunikasi erat kaitannya dengan bahasa yang digunakan untuk berkomunikasi. Bahasa tersebut dapat berupa bahasa yang verbal maupun bahasa yang non-verbal. Aktivitas yang dilakukan manusia pasti memiliki tujuan tertentu, termasuk komunikasi. Komunikasi memiliki tujuan salah satunya adalah untuk melestarikan dan mensosialisasikan norma-norma budaya masyarakat. Seperti yang dijabarkan oleh (Mulyana, 2012: 7) "Pada satu sisi, komunikasi merupakan mekanisme untuk mensosialisasikan norma-norma budaya masyarakat, baik secara horizontal, dari suatu masyarakat kepada masyarakat lainnya, ataupun secara vertikal, dari suatu generasi kepada generasi berikutnya." Sementara itu, Haviland (1999:393) menyebutkan bahwa, " Melalui bahasalah orang dalam setiap kebudayaan dapat mengkomunikasikan pengalaman, keprihatianan, dan kepercayaannya dari waktu yang lampau maupun waktu sekarang, dan meneruskannya kepada generasi berikutnya." Dari penjelasan tersebut maka dapat dikatakan salah satu tujuan komunikasi adalah melestarikan normanorma budaya dengan cara mensosialisasikannya dari suatu masyarakat ke masyarakat lainnya atau dari suatu generasi kepada generasi berikutnya. Dengan memanfaatkan komunikasi manusia dapat menyebarluaskan atau mensosialisasikan dan melestarikan norma-norma budaya yang dimilikinya.

Komunikasi kelompok (group communication) menurut (Effendy, 2003: 75) "komunikasi yang berlangsung antara seorang komunikator dengan sekelompok orang yang jumlahnya lebih dari dua orang." Dalam penjabarannya, komunikasi kelompok dapat dibagi menjadi dua jenis yaitu a) komunikasi kelompok kecil dan b) komunikasi kelompok besar. Dimana penggolongan komunikasi kelompok kecil atau komunikasi kelompok besar itu tidak dilihat dari jumlah pelaku komunikasi yang ada dalam kelompok tersebut, penggolongan ini dapat dilihat dari karakteristiknya. Peran kelompok sangat besar dalam mempengaruhi perilaku anggota kelompoknya. Hal ini disebut konformitas yang menurut Kiesler dan Kiesler (dalam Rakhmat,2001:150) adalah, “perubahan perilaku atau kepercayaan menuju (norma) kelompok sebagai akibat tekanan kelompok-yang real atau yang dibayangkan”. Salah satu penjelasan mengapa individu tunduk pada tekanan kelompok dijelaskan oleh Festinger dalam teori perbandingan sosial (social comparison theory). Festinger menyebutkan, "each human being has a need to evaluate his opinions and abilities and that when he cannot do so by objective social means he compares them with those of other people" (Festinger dalam Tubbs dan Moss, 1974:2006)

Pengertian tradisi menurut Kamus Besar Bahasa Indonesia adalah "adat kebiasaan turun-temurun (dari nenek moyang) yang masih dijalankan dalam masyarakat.” (KBBI Pusat Bahasa, 2011: 1483). Dari pengertian diatas dapat dipahami bahwa tradisi merupakan adat kebiasaan yang diwarisi secara turun temurun dan masih berlaku di masyarakat tertentu. Dengan begitu kata lain dari tradisi adalah kebiasaan yang diwariskan.

Sedangkan pengertian kebiasaan dalam konteks sosiologi menurut (Horton dan Hunt, 2014: 66) "kebiasaan (folkways) hanyalah suatu cara yang lazim yang wajar dan diulang-ulang dalam melakukan sesuatu oleh sekelompok orang." Terdapat titik persamaan dari kedua pengertian diatas bahwa keduanya merupakan aktivitas yang dilakukan dan terjadi dalam masyarakat. Sehingga dapatlah dikatakan bahwa tradisi merupakan aktivitas yang dilakukan berulang-ulang dan diwariskan turun-temurun dalam kelompok atau masyarakat tertentu.

Kongres I Masyarakat Adat Nusantara tahun 1999 dalam (Keraf, 2010: 361) manyatakan bahwa "Masyarakat adat adalah komunitas-komunitas yang hidup bedasarkan asal-usul secara turun temurun di atas suatu wilayah adat, yang memiliki kedaulatan atas tanah dan kekayaan alam, serta kehidupan sosial budaya yang diatur oleh hukum adat dan lembaga adat yang mengelola keberlangsungan kehidupan masyarakat."

Kerangka berpikir penelitian ini berangkat dari teori interaksi simbolik, teori ini berusaha memahami manusia dari sudut pandang subjek. Interaksi simbolik menyarankan (Mulyana, 2008: 70) "Bahwa perilaku manusia harus dilihat sebagai proses yang memungkinkan manusia membentuk dan mengatur perilaku mereka dengan mempertimbangkan ekspektasi orang lain yang menjadi interaksi mereka." Perspektif interaksi simbolik berpandangan bahwa manusia berperilaku tidak berdasarkan dorongan objek atau hal yang berada diluar diri mereka seperti lingkungan mereka hidup, adat budaya yang berlaku, kebutuhan atau tuntutan peran. Sebaliknya, perspektif ini beranggapan bahwa manusia berperilaku berdasarkan pada bagaimana mereka memaknai orang lain, objek, situasi atau bahkan diri mereka sendiri.

Dalam (Poloma, 2007: 257) dinyatakan bahwa "Interaksi simbolik dilakukan dengan menggunakan bahasa, sebagai satu-satunya simbol yang terpenting, dan melalui isyarat." Lalu Mead mempertegas dalam (Mulyana, 2008: 
83) bahwa "Tindakan verbal (bahasa) merupakan mekanisme utama interaksi manusia." Kensekuensi dari "penggunaan bahasa atau isyarat simbolik oleh manusia pada gilirannya memunculkan pikiran (mind) dan "diri” (self). Hanya melalui penggunaan simbol yang signifikan, khususnya bahasa, pikiran itu muncul.” (Mulyana 2008: 87) (Mulyana, 2008: 70) "Bahwa perilaku manusia harus dilihat sebagai proses yang memungkinkan manusia membentuk dan mengatur perilaku mereka dengan mempertimbangkan ekspektasi orang lain yang menjadi interaksi mereka." Perspektif interaksi simbolik berpandangan bahwa manusia berperilaku tidak berdasarkan dorongan objek atau hal yang berada diluar diri mereka seperti lingkungan mereka hidup, adat budaya yang berlaku, kebutuhan atau tuntutan peran. Sebaliknya, perspektif ini beranggapan bahwa manusia berperilaku berdasarkan pada bagaimana mereka memaknai orang lain, objek, situasi atau bahkan diri mereka sendiri.

\section{HASIL PENELITIAN DAN PEMBAHASAN \\ A. Temuan Penelitian}

Masyarakat adat Cireundeu tidak pernah secara sengaja memperkenalkan tradisi dan nilai adat yang mereka miliki kepada masyarakat luar. Tradisi dan nilai adat di Cireundeu diperkenalkan secara tidak langsung oleh media massa seperti televisi dan radio yang meliput serta membahas tentang masyarakat adat Cireundeu. Hal ini terjadi karena Masyarakat adat Cireundeu sudah terbiasa dengan kedatangan tamu dari pihak media massa baik itu media elektronik maupun media cetak. Media massa yang datang ke kampung Cireundeu biasanya meliput tradisi dan nilai adat yang ada di Cireundeu selain itu mereka juga mewawancarai tokoh masyarakat adat. Memang pada dasarnya masyarakat adat Cireundeu tidak pernah sedikit pun meminta atau mengundang para tamu dari pihak media itu untuk meliput Cireundeu. Akan tetapi para pihak media massa itu datang ke Cireundeu karena mengetahui Cireundeu dari informasi mulut ke mulut atau dari media massa yang sebelumnya pernah datang ke Cireundeu. Mereka datang karena Cireundeu memiliki tradisi dan nilai adat yang unik sehingga mereka meliputnya, dengan kata lain Cireundeu sering diminta untuk memperkenalkan tradisi dan nilai adatnya oleh media massa. Tradisi Cireundeu yang biasanya menarik perhatian media massa adalah tradisi mengonsumsi Singkong sebagai makanan pokok masyarakat adat Cireundeu. Media massa yang sering berkunjung dan meliput kampung adat Cireundeu adalah televisi dan radio. Sedangkan orang yang paling sering diwawancarai dan paling sering datanyai perihal tradisi dan nilai adat oleh media televisi dan radio adalah abah Widia.

Sementara itu, dalam upaya pelestarian nilai-nilai tradisi dan adat di kalangan remaja dan pemuda di kampung adat Cirendeu media sosial, khususnya Facebook dan WhatsApp lebih banyak digunakan. Media sosial berbasis jaringan internet ini digunakan untuk menyebarkan dan membagikan informasi tentang kegiatan atau aktivitas adat Cireundeu. Misalkan seperti yang dilakukan oleh kang Jajat (tokoh pemuda Kampung Adat Cireundeu) yang memperkenalkan tradisi Ngarajah di Puncak Salam melalui Facebook. Juga yang dilakukan oleh kang Yana (tokoh pemuda Kampung Adat Cireundeu) yang membagikan informasi, mengobrol dan berbincang tentang berbagai hal termasuk kegiatan-kegiatan adat melalui aplikasi WhatsApp dengan tujuan untuk menjaga komunikasi antara pemuda dan remaja anggota masyarakat adat Cireundeu. Komunikasi berupa perbincangan yang terjadi di dalam media sosial WA ini menjadi ajang silaturahmi untuk memperkuat tali persaudaraan antara remaja dan pemuda-pemuda adat Cireundeu. Dengan terwujudnya ikatan dan integritas yang kuat antara seluruh remaja dan pemuda adat Cireundeu maka menjaga dan melestarikan tradisi dan nilai adat dapat terwujud.

\section{B. Diskusi}

Carl I. Hovland menyebutkan bahwa komunikasi pada dasarnya adalah, "upaya yang sistematis untuk merumuskan secara tegas asas-asas penyampaian informasi serta pembentukan pendapat dan sikap" (Hovland dalam Effendy, 2002:10). Definisi Hovland ini menjelaskan bahwa komunikasi bukan hanya penyampaian informasi semata, melainkan juga pembentukan pendapat umum (public opinion) dan sikap publik (public attitude) yang memainkan peranan yang amat penting dalam kehidupan sosial dan budaya masyarakat. Bahkan secara tegas dalam definisinya secara khusus mengenai pengertian komunikasinya sendiri, Hovland mengatakan bahwa komunikasi adalah proses mengubah perilaku orang lain (Communications is the proces to modify the behavior other individuals) (Hovland dalam Effendy, 2003:10). Selanjutnya, Everett M. Rogers menyebutkan bahwa: "komunikasi adalah proses dimana dua orang atau lebih membentuk atau melakukan pertukaran informasi dengan satu sama lainnya, yang pada gilirannya akan tiba pada saling pengertian yang mendalam.(Rogers dalam Effendy, 2003:12) definisi Rogers ini secara tidak langsung telah menyiratkan bahwa tujuan dari komunikasi tidaklah hanya suatu pertukaran informasi (pesan) semata, tetapi adalah adanya perubahan sikap dan tingkah laku serta kebersamaan dalam menciptakan saling pengertian dari orang-orang yang ikut dalam suatu proses komunikasi. Rogers dalam Cangara:2000:18). Komunikasi dengan dukungan teknologi komunikasi telah membantu proses pemeliharaan dan pewarisan tradisi dan nilai-nilai budaya lokal masyarakan kampount Cirendeu.

Dengan diperkenalkannya tradisi dan nilai adat Cireundeu melalui media maka ini akan membuat tradisi dan nilai adat Cireundeu dikenal secara luas karena tradisi dan nilai adat tadi tersosialisasikan secara horizontal dari masyarakat adat Cireundeu pada masyarakat yang lain. Ini merujuk pada fungsi komunikasi massa yang diungkapkan oleh MacBride dalam (Cangara, 2000: 70-71) sebagai berikut : 
1. Informasi; yakni kegiatan untuk mengumpulkan, menyimpan data, fakta dan pesan, opini dan komentar, sehingga orang bisa mengetahui keadaan yang terjadi diluar dirinya, apakah itu dalam lingkungan daerah, nasional atau internasional.

2. Sosialisasi; yakni menyediakan dan mengajarkan ilmu pengetahuan bagaimana orang bersikap sesuai nilainilai yang ada, serta bertindak sebagai anggota masyarakat secara efektif.

3. Motivasi; yakni mendorong orang untuk mengikuti kemajuan orang lain elalui apa yang mereka baca lihat, dan dengar lewat media massa.

4. Bahan diskusi; menyediakan informasi sebagai bahan diskusi untuk mencapai persetujuan dalam hal perbedaan pendapat mengenai hal-hal yang menyangkut orang banyak.

5. Pendidikan; yakni membuka kesempatan untuk memperoleh pendidikan secara luas, baik untuk pendidikan formal di sekolah maupun untuk di luar sekolah. Jua meningkatkan kualitas penyajian materi yang baik, menarik, dan mengesankan.

6. Memajukan kebudayaan; media massa menyebarluaskan hasil-hasil kebudayaan melalui pertukaran program siaran radio dan televisi, ataukah bahan cetak seperti buku dan penerbitanpenerbitan lainnya. Pertukaran ini akan memungkinkan peningkatan daya kreativitas guna memajukan kebudayaan nasional masing-masing negara, serta mempertinggi kerja sama hubungan antarnegara.

7. Hiburan; media massa telah menyita banyak waktu luang untuk semua golongan usia dengan difungsikannya sebagai alat hiburan dalam rumah tangga. Sifat estetika yang dituangkan dalam bentuk lagu, lirik, dan bunyi maupun gambar dan bahasa, membawa orang pada situasi menimati hiburan seperti halnya kebutuhan pokok lainnya.

8. Integrasi; banyak bangsa di dunia dewasa ini diguncang oleh kepentingan-kepentingan tertentu karena perbedaan etnis dan ras. Komunikasi seperti satelit dapat dimanfaatkan untuk menjembatani mperbedaanperbedaan itu dalam memupuk dan memperkokoh persatuan bangsa.

Hal ini dengan jelas telah menunjukkan bahwa proses sosialisasi atau pengenalan tradisi dan nilai adat Cireundeu telah terjadi pada masyarakat luas. Sosialisasi yang dilakukan melalui media massa ini dalam jangka yang pendek akan membuat tradisi, nilai adat, dan masyarakat adat Cireundeu menjadi dikenal luas. Secara jangka panjang tradisi dan nilai adat yang telah dikenal secara tidak langsung akan membuat tradisi dan nilai adat itu terjaga dan terlestarikan keberadaannya. Merujuk pada fungsi komunikasi massa yang disampaikan MacBride khususnya pada poin ke-enam, bahwa komunikasi melalui media massa akan membantu memajukan tradisi dan nilai adat yang ada di Cireundeu. Dengan memajukan tradisi dan nilai adat Cireundeu pada masyarakat luas maka ini akan menjadi tradisi dan nilai adat tersebut semakin terjaga keutuhan dan keberadaannya. Semakin maju tradisi dan nilai adat Cireundeu semakin eksis dan kokoh keberadaannya.

\section{Mengapa anak muda milih media sosial}

Saat ini perkembangan teknologi informasi berjalan sangat pesat. Kecanggihan teknologi membuat facebook dapat diakses dimana saja, kapan saja dan melalui apa saja. Perkembangan teknologi yang digunakan oleh remaja tidak hanya sebatas untuk menambah pengetahuan dan sumber belajar, namun telah mempengaruhi proses pembentukan identitas remaja. Monks (2006) membagi batasan usia remaja dalam tiga fase, yaitu fase remaja awal (usia 12 tahun sampai 15 tahun), fase remaja tengah (usia 15 tahun sampai 18 tahun), dan fase remaja akhir (usia 18 tahun sampai 21 tahun). Proses pembentukan identitas diri remaja berlangsung dalam lingkup keluarga dan teman sebaya. Keinginan kuat remaja dalam berhubungan dengan teman sebaya membutuhkan berbagai sarana, salah satu melalui jejaring sosial facebook. Jejaring sosial facebook telah menjadi tempat bagi para remaja untuk mengungkapkan berbagai pemikiran dan perasaan yang mereka miliki. Berkaitan dengan hal ini Nurkinan menyebutkan bahwa,

Media sosial dianggap sebagai media yang baru dan lebih menarik perhatian masyarakat dari berbagai kalangan. Berkaitan dengan itu, media sosial menjadi salah satu platform yang menyebarkan informasi dengan mudah, cepat dan dengan biaya yang relative murah. Selain itu, kehadiran media sosial mampu mengubah pola penyebaran informasi. (Nurkinan, 2017:33)

Klasifikasi pemanfaatan teknologi komunikasi dalam mempertahankan tradisi dan nilai adat ini dilihat dari beberapa aspek yaitu jenis media, pengguna media komunikasi, cara memanfaatkan teknologi komunikasi dalam mempertahankan tradisi dan nilai adat, dan target dari media komunikasi.

Dari aspek pengguna teknologi komunikasi maka dapat dibagi menjadi dua yaitu para nonoman/pemuda dan para sepuh. Pengguna dalam hal ini adalah mereka yang menggunakan atau memanfaatkan teknologi komunikasi dalam 
mempertahankan tradisi dan nilai adat. Teknologi komunikasi yang penggunanya adalah sepuh yaitu televisi dan radio. Dalam hal ini sepuh menggunakan televisi dan radio untuk memperkenalkan tradisi dan nilai adat ini bersifat tidak langsung. Yakni seperti yang sudah dijelaskan sebelumnya bahwa masyarakat adat Cireundeu memperkenalkan tradisi dan nilai adat melalui televisi dan radio karena adanya liputan dan wawancara yang dilakukan pihak televisi dan radio pada masyarakat adat Cireundeu. Menurut pengakuan abah Widia (tokoh adat Cireundeu) yang paling sering di wawancarai oleh televisi dan radio adalah abah Widia sendiri selaku salah satu tokoh adat. Sedangkan teknologi komunikasi yang penggunanya adalah remaja dan pemuda adat Cireundeu adalah media sosial Facebook dan WhatsApp. Pengguna media sosial Facebook dan WhatsApp adalah remaja dan pemuda adalah karena generasi pemuda dan para remaja lah yang paham dan mengerti menggunakan media sosial tersebut, sedangkan para orang tua dan sepuh tidak memahaminya.

Dilihat dari aspek cara memanfaatkan teknologi komunikasi dalam mempertahankan tradisi dan nilai adat ini terdapat dua cara yaitu menjaga silaturahmi/tali persaudaraan dan memperkenalkan tradisi dan nilai adat. Dalam menjaga tali silaturahmi ini para nonoman dan remaja masyarakat adat Cireundeu menggunakan teknologi komunikasi WhatsApp. WhatsApp dalam hal ini berfungsi sebagai sarana atau media untuk membicarakan berbagai hal baik tentang hal-hal yang ringan hingga hal-hal yang terkait dengan adat. Komunikasi berupa perbincangan dalam Whats App ini akan membentuk ikatan persaudaraan dan integritas satu sama lain antara remaja serta para nonoman/pemuda masyarakat adat Cireundeu. Dengan adanya ikatan yang kuat dalam suatu komunitas maka akan mudah untuk mempertahankan tradisi dan nilai adatnya.

Sedangkan cara memanfaatkan teknologi dalam mempertahankan tradisi dan nilai adat ini salah satunya adalah dengan memperkenalkan tradisi dan nilai adat pada masyarakat luas melalui media komunikasi. Beberapa media komunikasi yang digunakan masyarakat adat Cireundeu untuk memperkenalkan tradisi dan nilai adat pada masyarakat luas yaitu televisi, radio, dan Facebook. Seperti yang sudah dijelaskan sebelumnya bahwa memperkenalkan tradisi dan nilai adat melalui televisi dan radio dilakukan secara tidak langsung. Sedangkan jika menggunakan Facebook sesuai dengan penuturan kang Jajat bahwa ia pernah memperkenalkan tradisi dan nilai adat masyarakat adat Cireundeu pada masyarakat luas. Sedangkan dari aspek target dari media komunikasi terbagi dua menjadi internal dan eksternal. Target internal adalah anggota masyarakat adat Cireundeu terutama pemuda dan remaja, media komunikasi yang termasuk aspek ini adalah WhatsApp. Media komunikasi WhatsApp menjadi aspek target internal karena WhatsApp dimanfaatkan oleh remaja dan pemuda Cireundeu untuk menjaga integritas, silaturahmi, dan tali persaudaraan satu sama lain.

Pemanfaatan ini bentuknya yaitu perbincangan dalam grup masyarakat adat Cireundeu yang isinya mayoritas adalah remaja dan pemuda adat Cireundeu. Sedangkan target eksternal adalah seluruh masyarakat luar Cireundeu, media komunikasi yang termasuk aspek ini adalah televisi, radio, dan Facebook. Televisi, radio, dan Facebook termasuk dalam aspek ini adalah kerena sifat dari media komunikasi ini yang mampu menyebarluaskan informasi termasuk informasi tentang tradisi dan nilai adat secara massal kepada siapa pun dan dimana pun. Untuk memudahknan pemahaman peneliti sajikan model dari uraian ini sebagai berikut:

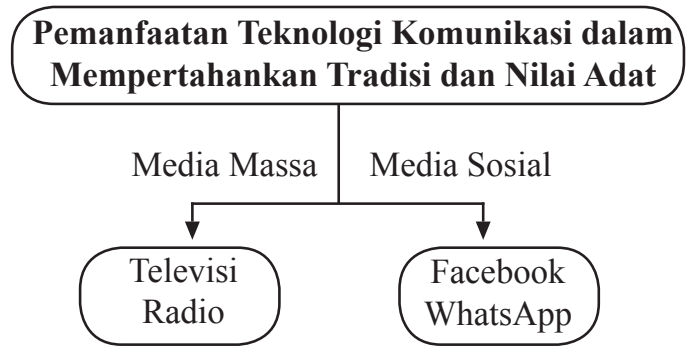

Sepuh Remaja dan Pemuda

Dari model diatas, dapat dijelaskan menurut klasifikasi aspek-aspek aktivitas komunikasi masyarakat adat Cireundeu. Kolom kiri dan kanan mewakili aspek jenis media, dimana kolom kiri adalah jenis media massa sedangkan kolom kanan jenis medianya adalah media sosial. Selain dari itu kolom tersebut juga mewakili aspek pengguna teknologi komunikasi. Kolom kiri adalah teknologi komunikasi yang digunakan oleh Sepuh untuk mempertkenalkan tradisi dan nilai adat, sedangkan kolom kanan adalah teknologi komunikasi yang digunakan oleh para remaja dan nonoman (pemuda). Warna yang terdapat pada model tersebut mewakili aspek cara mempertahankan tradisi dan nilai adat. Warna kuning mewakili cara mempertahankan tradisi dan nilai adat dengan bentuk memperkenalkan tradisi dan nilai adat pada masyarakat luar. Sedangkan warna biru mewakili cara mempertahankan tradisi dan nilai adat dengan bentuk menjaga silaturahmi dan mempererat tali persaudaraan. Sedangkan bentuk oval dan persegi panjang mewakili target dari media komunikasi, bentuk oval mewakili target internal sedangkan bentuk persegi panjang mewakili target eksternal. 


\section{KESIMPULAN}

Pemanfaatan media konvensional untuk mempertahankan tradisi dan nilai adat di Cireundeu ini sifatnya tidak langsung, jadi masyarakat Cireundeu tidak pernah ingin menonjolkan ke-khasannya melalui media. Karena media yang meliput Cireundeu menyebarluaskannya kepada masyarakat luas maka tradisi dan nilai adat Cireundeu tadi jadi dikenal dan diketahui oleh masyarakat umum. Media konvensional seperti radio yang digemari oleh para orang tua digunakan untuk melestarikan nilai-nilai dan filosofi kehidupan adat. Para remaja lebih memilih menggunakan media sosial untuk menyampaikan kegiatan-kegiatan adat dan untuk menjaga nilai-nilai silaturahmi diantara remaja kampung adat Cirendeu. Bentuknya yaitu dengan cara menginformasikan kegiatan adat, membagikan foto-foto dan video kegiatan adat di grup Facebook dan WhatsApp (WA).

\section{DAFTAR PUSTAKA}

Cangara, Hafid, 2000. Pengantar Ilmu Komunikasi, Cet. II: Jakarta: PT. Raja Grafindo Persada,

Depdiknas. 2011. Kamus Besar Bahasa Indonesia: Pusat Bahasa Edisi Keempat. Jakarta: Gramedia Majalah

Effendy, Onong Uchjana. 2003. Ilmu, Teori dan Filsafat Komunikasi. Bandung: Citra Aditya Bakti.

Hartanto, Aat. 2010. Panduan Aplikasi Smartphone. Jakarta: Gramedia Pustaka Utama Horton, Paul B. dan Chester L. Hunt. 2014. Sosiologi. Jakarta: Erlangga

Haviland, Wlliam A., 1999. Antropologi jilid 1, penerjemah : RG Soekadijo, Jakarta:Erlangga.

Keraf, A. S. 2010. Etika Lingkungan Hidup. Jakarta: Penerbit Buku Kompas .

Koentjaraningrat,1990. Pengantar Ilmu Antropologi. Jakarta. Rineka Cipta

Mulyana, Deddy, 2008. Metodologi Penelitian Kualitatif: Paradigma Baru dan Ilmu Sosial Lainnya. Bandung: Remaja Rosdakarya.

Mulyana, Deddy, 2012. Ilmu Komunikasi: Suatu Pengantar. Bandung: Remaja Rosdakarya.

Nurkinan, 2017, Dampak Media Online terhadap Perkembangan Media Konvensional, Jurnal

Politikom Indonesiana, Vol.2 No.2 November 2017, e-ISSN:2528-2069

Poloma, Margaret M. 2007. Sosiologi Kontemporer. Jakarta: Raja Grafindo.

Rakhmat, Jalaluddin, 2001. Psikologi Komunikasi, edisi revisi cetakan ke-16. Bandung: Remaja Rosdakarya

Tubbs, stewart L. and Sylvia Moss, 1974. Human Communication: An Interpersonal Perspective.New York:Random House.

Yin, Robert, K, 2009, Studi Kasus: Desain dan Metode, Jakarta: Rajawali Press.

\section{Jurnal}

Fauzan, Rikza, dan Nashar, 2017, "Mempertahankan Tradisi, Melestarikan Budaya": Kajian Historis dan Nilai Budaya Lokal Kesenian Terebang Gede di Kota Serang, Jurnal Candrasangkala, ISSN: 2477-2771, E-ISSN: $2477-8214$ Vol 3 No.1 Tahun 20171.

Setiawan, D., (2018), Dampak Perkembangan Teknologi Informasi dan Komunikasi Terhadap Budaya,. SIMBOLIKA, Vol. 4 (1) April (2018) hal. 62-72 ISSN 2442- 9198X (Print), ISSN 2442-9996 http://ojs.uma.ac.id/index.php/ simbolika, diakses 16 April 2019.

Sularso, Pryo dan Yuli Maria, 2017, ”Upaya Pelestarian Kearifan Lokal melalui Ekstrakurikuler Karawitan di SMP Negeri 1 Jiwan Tahun 2016", Citizenship, Jurnal Pendidikan Pancasila dan Kewarganegaraan Universitas PGRI Madiun Vol 5 No 1 April 2017, hal 1-12, http://e-journal.unipma.ac.id/index.php/citizenship p-ISSN: 2302-433Xp e-ISSN 2579-5740, diakses 16 April 2019. 
